\title{
INCREASING THE EFFICIENCY OF THE TEXTILE AND GARMENT INDUSTRY OF VIETNAM IN THE CONTEXT OF THE DEPENDENCE ON FOREIGN SUPPLIERS AND INVESTORS
}

\author{
Dao Thanh Binh \\ School of Economics and Management of Hanoi University of Science and Technology, \\ Hanoi, Vietnam \\ Tran Si Lam \\ Foreign Trade University, Hanoi, Vietnam
}

Nguyen Danh Nguyen

Hanoi University of Science and Technology, Hanoi, Vietnam

Tran Thi Bich Ngoc

Hanoi University of Science and Technology, Hanoi, Vietnam

Galina Anzelmovna Barysheva

Tomsk Polytechnic University, Tomsk, Russia

\begin{abstract}
The purpose of this study is to determine the optimal proportions of interaction between foreign and domestic suppliers and investors in the institutional structure of the Vietnam Textile and Garment Industry (VTGI). Based on a survey of representatives of 388 VTGI enterprises, the economic efficiency of the industry's enterprises and the degree of dependence on foreign suppliers and investors are assessed. The survey was conducted in a stable market environment (April-June 2019) and in a crisis (April-June 2020). Regression models of the influence of indicators of dependence on foreign suppliers and investors on the enterprise performance indicator are constructed. By solving a system of equations (dependence functions), the optimal proportions of the structure of interaction between foreign and domestic suppliers and investors are determined quantitatively in order to maximize the economic efficiency of clothing and textile enterprises in the context of crisis manifestations in the market conditions of operation.
\end{abstract}

Keywords: Vietnam, textile industry, garment industry, foreign investment, domestic supplier, crisis

DOI: http://dx.doi.org/10.15549/jeecar.v7i3.598 


\section{INTRODUCTION}

Vietnam is the fourth largest exporter of textiles, garments and clothing worldwide after China, the European Union and Bangladesh (Statista, 2020). In 2019, the textile and garment industry reached an export turnover of more than US\$ 39 billion, which accounted for $16 \%$ of GDP. In the past five years, the textile industry has continuously grown at an average rate of 17 percent annually (General Statistics Office of Vietnam, 2020). As a result, garments and clothing have become the country's third largest export product (Statista, 2020).

Since the 1990s, Vietnam has attracted impressive foreign direct investment (FDI) and has made spectacular progress in economic development. According to the Ministry of Planning and Investment (MPI), as of December 20,2019 , the country has 30,827 valid projects with a total registered capital of US\$ 362.58 billion, of which the accumulated realized capital of FDI projects was estimated at US\$ 211.78 billion, or $58.4 \%$ (Ministry of Planning and Investment, 2020). In recent years, foreign investment has shifted from mainly Cut, Make and Trim (CMT) activities to more upstream sectors such as fabric production and dyeing (Hikmah et al., 2020; Saleh et al., 2020). In 2019, more than 80 percent of FDI in the industry consisted of manufacturing fabrics and raw materials projects (General Statistics Office of Vietnam, 2020). It should be noted that with the spread of the SARS-CoV-2 virus and the introduction of a general quarantine against the pandemic in 2020, the clothing and textile industry in Vietnam was the most vulnerable due to the fact that the supply chain of the industry mainly depended on several key foreign partners of suppliers and markets for exporting textile products. Although foreign invested enterprises (FIEs) in the textile and garment manufacturing sector accounted only for nearly $25 \%$ of the total number (General Statistics Office of Vietnam, 2020), they contributed about 58-62\% of the export turnover in the survey years because FIEs have advantages over DEs not only in advanced machinery and technology, but also in stable and profitable orders transferred from parent corporations, as most of them are subsidiaries in MNC's affiliates. Up to 80 percent of the fabric source for processing exports was imported, of which 50 percent came from China (Nguyen, 2020); in 2019, VTGI's exports to China totaled US\$ 4.2 billion, while imports from it were worth US\$ 11.5 billion. Notably, VTGI annually imported nearly $60 \%$ of fabric, $55 \%$ of yarn and $45 \%$ of its auxiliary materials for production from China, and US\$ 3 billion was spent to import raw cotton from the United States accounting for over $50 \%$ of total imported cotton, as US cotton products are assessed as the best for the Vietnam's spinning industry ( $\mathrm{Ha}$, 2019).

The FIE's advantages serve as a convincing answer why a technology and capital gap exists between FIEs and domestic enterprise (DEs). DEs need large working capital for maintaining production and technological renovation, hiring experienced foreign experts; nevertheless, they face difficulty accessing credit from banks and related funding sources. Recognizably, the VTGI's dependence on FDI is reflected in: (a) the direct contribution to production volume and export growth of the textile and garment sector; (b) spillover effects on technology and management experience; (c) the coverage of long-term capital shortages; and (d) employment for surplus agricultural labor caused by economic restructuring. Therefore, identifying the root causes and taking measures to deal with this situation is an actual issue, and as a result this study is aimed at determining the qualitative and quantitative characteristics of the functioning of the VTGI depending on the level of interaction of foreign suppliers and capital in the structure of the industry.

\section{LITERATURE REVIEW}

Previous studies have been inconsistent in their conclusions about the relationship between external participation and performance in the garment and textile industry. The authors attribute this discrepancy to a mismatch between external participation and the business environment. Based on the concept of correspondence between information processing capabilities and needs from information processing theory, researchers develop patterns of correspondence between external participation and the business environment and investigate their impact on 
productivity. Theoretically, globalization, technological advance and capital constraints put pressure on firms to innovate in a cooperative way. Since firms cannot compete in isolation, they need to develop long-term relationships with partners to forge a clear path to success (Pérez \& Cambra-Fierro, 2015).

In the past decade, the VTGI, as a laborintensive industry, has risen strongly thanks to the advantages of low labor cost, favorable geographical location for logistics and the suitability of textile and garment work to the Vietnamese people, as it is an ancient Vietnamese traditional profession. While there are many research works on the textile and garment sector in Vietnam, they come mainly from stock exchanges or private research organizations such as Phu Hung Securities (2019), Military Bank Securities (2018), FPT Securities (Thuan, 2017) in the form of annual or periodic reports with preliminary analysis of the current development of separate industries. Other studies usually have touched specific issues such as value-added chain analysis and low production profit (Chae et al., 2017; Tescari \& Brito, 2016; Cai et al., 2016), or examine the development of the textile and garment manufacturing industry in the context of market-oriented liberalization (Angie, 2012). Huong and Lam (2016), applying Michael E. Porter's Diamond Model (Vlados, 2019) to access capacities of the VTGI's enterprises, concluded that the lowest competitiveness of Vietnam in comparison with China was related to the lack of supporting industries (SIs). Currently, there is no comprehensive scientific study indicating the underlying cause of the core problem of import dependence that the VTGI is facing. Therefore, this study aims to explore the problem of low production efficiency of the VTGI in relation to import dependence and to examine the extent of dependence on sourcing overseas and external resources in general, determining the reasons that affect VTGI's participation in global supply chains (GSCs) and global value chans (GVCs).

\section{METHODS AND MATERIALS}

Forming a system of indicators for evaluating the effectiveness of enterprises and their dependence on interaction with foreign

\section{suppliers and investors}

The questionnaire method was used to obtain quantitative estimates of the effectiveness of the VTGI and the factors that affect it, Statistics on the volume of imports of products and technologies, and foreign investment in the industry, do not provide an objective assessment of the degree of dependence on foreign suppliers and investors, as they are averaged across the industry. There are no data on these indicators for business entities. In this regard, a questionnaire was used to obtain relevant data at the level of business entities.

The survey was conducted in two stages among lower, middle and senior managers of 388 VTGI enterprises, regardless of the size of the business and geography of activity. The total number of respondents is 1,164 . The survey was conducted in person and remotely in two stages: during April-June 2019 and during AprilJune 2020. All procedures were identical at these stages. The composition of respondents was also unchanged at $96 \%$. The $4 \%$ variability in the composition of respondents is related to the inability to get answers to the questionnaire questions of some respondents at the second stage of the survey who participated in the first stage. Despite the non-numerical representation from each enterprise ( 3 people), the objectivity of the evaluation results is evidenced by the coefficient of variation of ratings on the questionnaire questions, not exceeding $10 \%$, within the enterprise. The sufficiency of the formed sample population is estimated using the formula (1) (Reid, 2015):

$$
s=\frac{Z(p)^{2} \cdot v \cdot(1-v)}{e^{2}},
$$

where $s$ is the minimum size of the sample population sufficient to ensure the representativeness of the research results;

$Z(p)$ is the normalized deviation;

$p$ is the confidence probability;

$V$ is the deviation of the sample;

$\varepsilon$ is the acceptable error level.

For a large general population with a confidence probability of $95 \%$ and a confidence interval of $\pm 5 \%$, the minimum requirements for the size of the sample population are 384 . Exceeding the sample sufficiency standards 
indicates that the evaluation results are representative.

Respondents were asked to evaluate statements related to the activities of the company they represent on a 10-point scale.
The list of indicators is given in Table 1 . As the degree of agreement with the statement increases, the score increases from 1 (minimum score) to 10 (maximum score).

Table 1. Questions aimed at evaluating the performance of VTGI enterprises and the degree of dependence on foreign suppliers and investors

\begin{tabular}{|l|l|}
\hline Question & Convention* \\
\hline Indicators for evaluating the company's performance** & \\
\hline Your company has been consistently profitable over the past year & $X 1$ \\
\hline $\begin{array}{l}\text { Over the past year, the company has not participated in court proceedings related } \\
\text { to its insolvency, late fulfillment of obligations to staff and contractors }\end{array}$ & $X 2$ \\
\hline Over the past year, the company has not had significant staff reductions & $X 3$ \\
\hline Salaries are paid on time and in full & $X 4$ \\
\hline Salaries have dynamic growth & $X 5$ \\
\hline The company is competitive in the domestic market & $X 6$ \\
\hline The company is competitive in foreign markets & $X 7$ \\
\hline Indicators of dependence on foreign suppliers and investors & \\
\hline The company uses foreign technologies & $X 8$ \\
\hline Foreign companies play a dominant role in the supply of technologies & $X 9$ \\
\hline The company largely operates on foreign capital & $X 10$ \\
\hline Participation of foreign investors in research and design development is crucial & $X 11$ \\
\hline The company uses the services of foreign outsourcers & $X 12$ \\
\hline $\begin{array}{l}\text { Foreign companies participate in the development of the company's marketing } \\
\text { policy }\end{array}$ & $X 13$ \\
\hline Foreign suppliers play a dominant role in the supply of raw materials & $X 14$ \\
\hline $\begin{array}{l}\text { The company uses the services of foreign companies when developing its } \\
\text { development strategy and management plan for the short, medium and long-term } \\
\text { periods }\end{array}$ & $X 15$ \\
\hline
\end{tabular}

* - symbol of the indicator (variable) corresponding to the score for the question

** - an enterprise is an enterprise that the Respondent is a representative of

The list of questions in the questionnaire was based on a synthesis of scientific literature on the role of foreign suppliers and investors in ensuring the efficiency of enterprises in different countries and sectors of the economy (Xiao et al., 2019; Aydın \& Kulali, 2018; Chae et al., 2017; Tescari \& Brito, 2016; Cai et al., 2016). The reliability of the proposed questionnaire was evaluated using the Cronbach's alpha coefficient calculated from the respondents' estimates using the Statistica 12.0 program. The calculated coefficient is 0.86 with a critical level of 0.7 (Dubina, 2006). Exceeding the calculated value over the critical value indicates the reliability of the questionnaire.

The results were statistically processed using the arithmetic mean scores of respondents representing a single enterprise. All the indicators (Table 1) are stimulants: the highest rating indicates the highest efficiency and the highest degree of dependence on foreign suppliers. Therefore, the integrated assessment of enterprise efficiency $\left(I_{e f}\right)$ and dependence on foreign suppliers and investors $\left(I_{\text {for }}\right)$ is calculated 
as the arithmetic mean of the indicators $X 1-X 7$ и $X 8-X 15$, respectively.

Development of a mathematical model for assessing the functional subordination of an enterprise from foreign suppliers and investors

The presence of causal relationships between the integral indicators of $I_{e f}$ and $I_{\text {for }}$ was checked using the Granger causality test. The use of the test was made possible due to the stationary nature of the variables evaluated using the extended Dickey-Fuller method. The Eviews 10 program was used for checking stationarity and causality.

The Granger causality test was used to evaluate regression of the form (formula 2 ) and test the null hypothesis that $\beta_{1}=\ldots=\beta_{p}=0$ (Ruan et al., 2018).

$$
\left\{\begin{array}{l}
y_{t}=\alpha_{0}+\sum \alpha_{j} \cdot y_{t-j}+\sum \beta_{j} \cdot x_{t-j}+\varepsilon_{t} \\
x_{t}=\alpha_{0}+\sum \alpha_{j} \cdot x_{t-j}+\sum \beta_{j} \cdot y_{t-j}+u_{t}
\end{array},\right.
$$

where $y, x$ is the dependent and independent variables $\left(I_{e f}\right.$ and $\left.I_{\text {for }}\right)$;

$$
\begin{aligned}
& \alpha_{0}, \alpha_{j}, \beta_{j} \text { are the regression coefficients; } \\
& t-j \text { is the time lag; } \\
& \varepsilon_{t}, u_{t} \text { is the error. }
\end{aligned}
$$

Based on the established causal relationships, a one-factor regression model was built, the dependent variable of which was the $I_{e f}$ indicator, the independent - $I_{\text {for }}$ for the enterprises of the sample population. Two models were built - one according to the survey data for 2019 and the other for 2020. The sample for constructing models in both cases was 388 observations. The type of model was selected based on the criterion for maximizing the indicators of statistical significance, Fisher's and Student's test.

\section{RESULTS}

Dependence of VTGI on foreign suppliers and investors

The survey results confirmed the high degree of dependence of enterprises on foreign suppliers and investors (Table 2).

Table 2. Average values of indicators of dependence of VTGI enterprises on foreign suppliers and investors

\begin{tabular}{|l|l|l|l|}
\hline Indicator & Average value for the sample & Indicator & Average value for the sample \\
\hline$X 8$ & 8.7 & $X 12$ & 8.8 \\
\hline$X 9$ & 7.4 & $X 13$ & 7.0 \\
\hline$X 10$ & 3.3 & $X 14$ & 8.4 \\
\hline$X 11$ & 7.6 & $X 15$ & 6.2 \\
\hline
\end{tabular}

For all indicators, except for $X 10$, the marks exceed the average level - 5 points. For all indicators, with the exception of X10, the scores exceed the average level - 5 points. The enterprises are most dependent on foreign outsourcers ( 8.8 points on average for the sample), supplies of foreign technologies (8.7 points), supplies of foreign raw materials ( 8.4 points). Enterprises are least dependent on foreign capital, but its role is important in ensuring the efficiency of enterprises since it has a greater impact on large enterprises that provide the bulk of production and export of products.

Causal relationships between indicators of dependence on foreign suppliers and investors and an indicator of enterprise performance 
For the analytical expression of the strength and nature of the influence of enterprises' dependence on foreign suppliers and investors on their efficiency, the integral indicators $I_{e f}$ and
$I_{\text {for }}$ were calculated. The primary task of modeling was to check the time series for stationarity, the results of which are given in Table 3.

Table 3. Indicators of checking the stationarity of time series of the efficiency of VTGI enterprises and their dependence on foreign suppliers and investors using the extended Dicky-Fuller method

\begin{tabular}{|c|c|c|c|}
\hline Indicator & Specification & Prob.* & $\begin{array}{l}\text { Conclusion about the } \\
\text { stationarity of the } \\
\text { series }\end{array}$ \\
\hline \multicolumn{4}{|c|}{ Based on the results of the 2019 survey (under stable conditions) } \\
\hline$I_{e f}$ & $I^{* *}, O^{* * *}$ & 0.0112 & Stationary \\
\hline$I_{\text {for }}$ & $I, 0$ & 0.0090 & Stationary \\
\hline \multicolumn{4}{|c|}{ Based on the results of the 2020 survey (in crisis conditions) } \\
\hline$I_{e f}$ & $I, 0$ & 0.0184 & Stationary \\
\hline$I_{\text {for }}$ & $I, O$ & 0.0105 & Stationary \\
\hline
\end{tabular}

* is probability of accepting the null hypothesis that the time series is non-stationary

${ }^{* *}$ stands for Intersep and means specification of a time series relative to a constant

*** is level

The time series tested by the extended Dickey-Fuller method were stationary with an error rate not exceeding $1.84 \%$. The stationarity of time series allowed us to use them to check causal relationships and build a model without additional transformations. Different business conditions determined the need to study the influence of enterprises' dependence on foreign suppliers and investors on their efficiency using two data sets: according to the results of the 2019 survey (as a period of stability) and the 2020 survey (as a period of crisis caused by the COVID-19 pandemic).

The results of testing for the Granger causality of the relationship between the efficiency indicator and dependence on foreign suppliers and investors are shown in Table 4.

Table 4. Statistical indicators of the Granger causality test between the performance indicators of VTGI enterprises and their dependence on foreign suppliers and investors

\begin{tabular}{|c|c|c|}
\hline Null hypothesis & Prob. $^{*}$ & Direction of causation \\
\hline \multicolumn{3}{|c|}{ Based on the results of the 2019 survey (under stable conditions) } \\
\hline$I_{e f}$ does not Granger Cause $I_{\text {for }}$ & 0.0904 & $I_{\text {ef }} \rightarrow I_{\text {for }}$ \\
\hline$I_{\text {for }}$ does not Granger Cause $I_{e f}$ & 0.0067 & $I_{\text {for }} \rightarrow I_{e f}$ \\
\hline \multicolumn{3}{|c|}{ Based on the results of the 2020 survey (in crisis conditions) } \\
\hline$I_{e f}$ does not Granger Cause $I_{\text {for }}$ & 0.2581 & $I_{e f} \rightarrow I_{\text {for }}$ \\
\hline$I_{\text {for }}$ does not Granger Cause $I_{e f}$ & 0.0211 & $I_{f o r} \rightarrow I_{e f}$ \\
\hline
\end{tabular}

${ }^{*}$ means that the probability of accepting the null hypothesis that there is no causal relationship

In conditions of stability and crisis, the company's dependence on foreign suppliers and investors

has a significant impact on efficiency. The probability of accepting the null hypothesis that there is no causal relationship does not exceed $2.11 \%$. The inverse effect of efficiency on dependence on foreign suppliers and investors is insignificant at a significance level of 0.05 .

Optimal relations between foreign and domestic suppliers and investors to ensure the efficiency of VTGI enterprises

The nature of the influence of dependence on foreign suppliers and investors on the efficiency 
of enterprises is determined by constructing linear, logarithmic, exponential, power, and polynomial regression models. As a result, the models with the highest accuracy are presented
- the highest indicators of statistical significance (Student's and Fisher's criteria). The results are shown in Table 5.

Table 5. Models of the influence of dependence on foreign suppliers and investors on the efficiency of enterprises in the VTGI

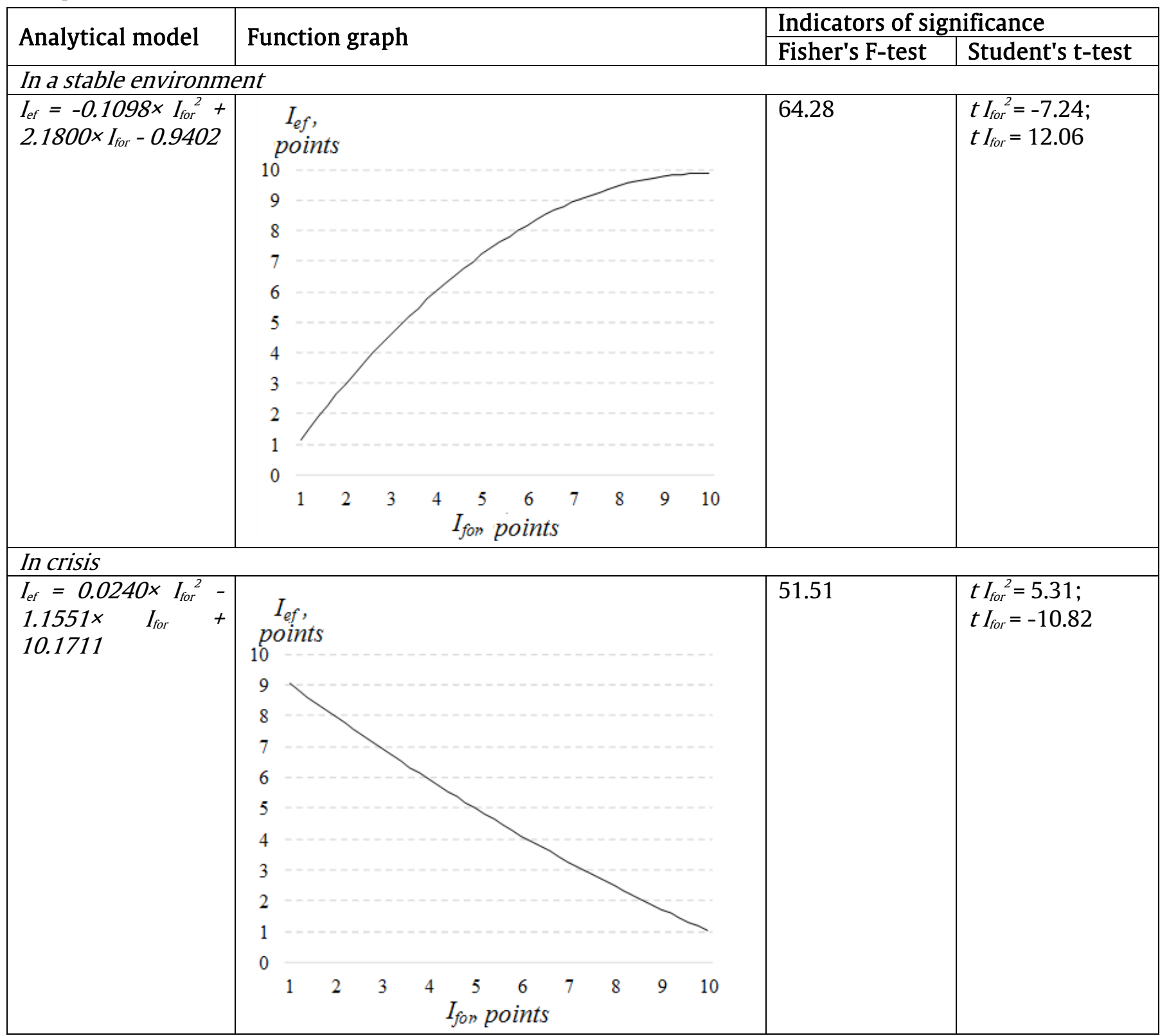

The revealed dependencies indicate that in conditions of stability, the growth of dependence on foreign suppliers and investors is a stimulus for the development of the VTGI. The adequacy of the constructed models is evidenced by the Fisher and Student criteria, the calculated values of which are given in Table 5, at a significance level of 0.05 , and which exceed the tabular values. The critical values of Fisher's F-test are 3.03, and the Student's t-test - 1.966.

According to Vietnam Customs' statistics (2020), by the end of the second quarter of 
2020, the total import - export turnover of the country reached US\$240.11 billion, down $1.4 \%$ (equivalent to a decrease of US\$ 3.29 billion) over the same periodof 2019, of which the export value was US\$ 122.79 billion USD, up $0.2 \%$. The value of 2020 imports was US\$ 117.33 billion, down 2.9\%; exports of textile and garment products was estimated at US\$ 13.18 billion, down $12.7 \%$ over the same period in 2019 (Vietnam Customs, 2020).

Generally, compared to the export growth rate of the whole country, in the first 6 months of 2020 the VTGI had negative growth in all items as shown in Table 6.

Table 6. VTGI export and import goods in the first half of 2019 and the first half of 2020

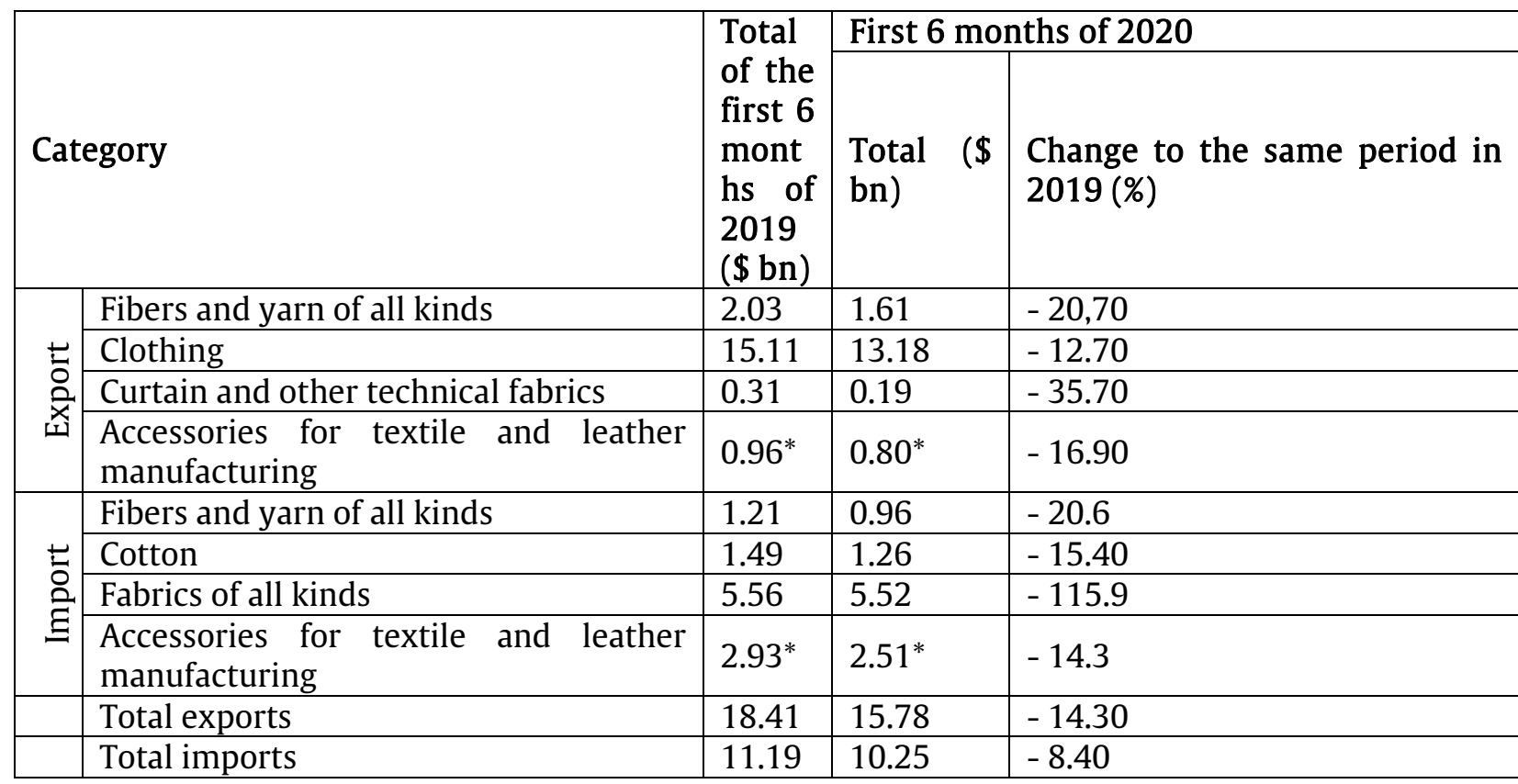

* - accessories import and export of both textile and leather manufacturing are summed together in one sub-category in customs statistics

Source: Compiled by the authors from Vietnam Customs (2020).

With the epidemic scenario that has lasted until the end of 2020, the estimated total world textile and apparel imports will only reach US\$ 600 - 640 billion, a decrease of $15-20 \%$ compared to US\$ 755 billion in 2019 (Texprocil, 2020). A study by India's Ranking and Research forecasts that demand for yarn, fabric, and apparel will likely decline by $25-35 \%$ in fiscal year 2021 (Dilip, 2020). Within this context of the market situation, VTG exports in the second half of 2020 are estimated to decrease by 14$18 \%$ over the same period, bringing the total export turnover in 2020 to about US\$ 32.75 billion, down about 16\% compared to 2019 (Anh \& Hanh, 2020). As the results show, businesses that are more dependent on foreign suppliers and investors are more affected by the COVID19 pandemic. To find a balance between the ratio of foreign and domestic suppliers and investors, a system of equations has been solved (formula 3 ), in which the 1st equation meets the conditions of stability and the 2nd the conditions of the crisis.

$$
\left\{\begin{array}{l}
I_{\text {ef }}=-0.1098 \times I_{\text {for }}{ }^{2}+2.1800 \times I_{\text {for }}-0.9402 \\
I_{\text {ef }}=0.0240 \times I_{\text {for }}{ }^{2}-1.1551 \times I_{\text {for }}+10.1711
\end{array}\right.
$$


The graphical solution of the system of equations is shown in Figure 1.

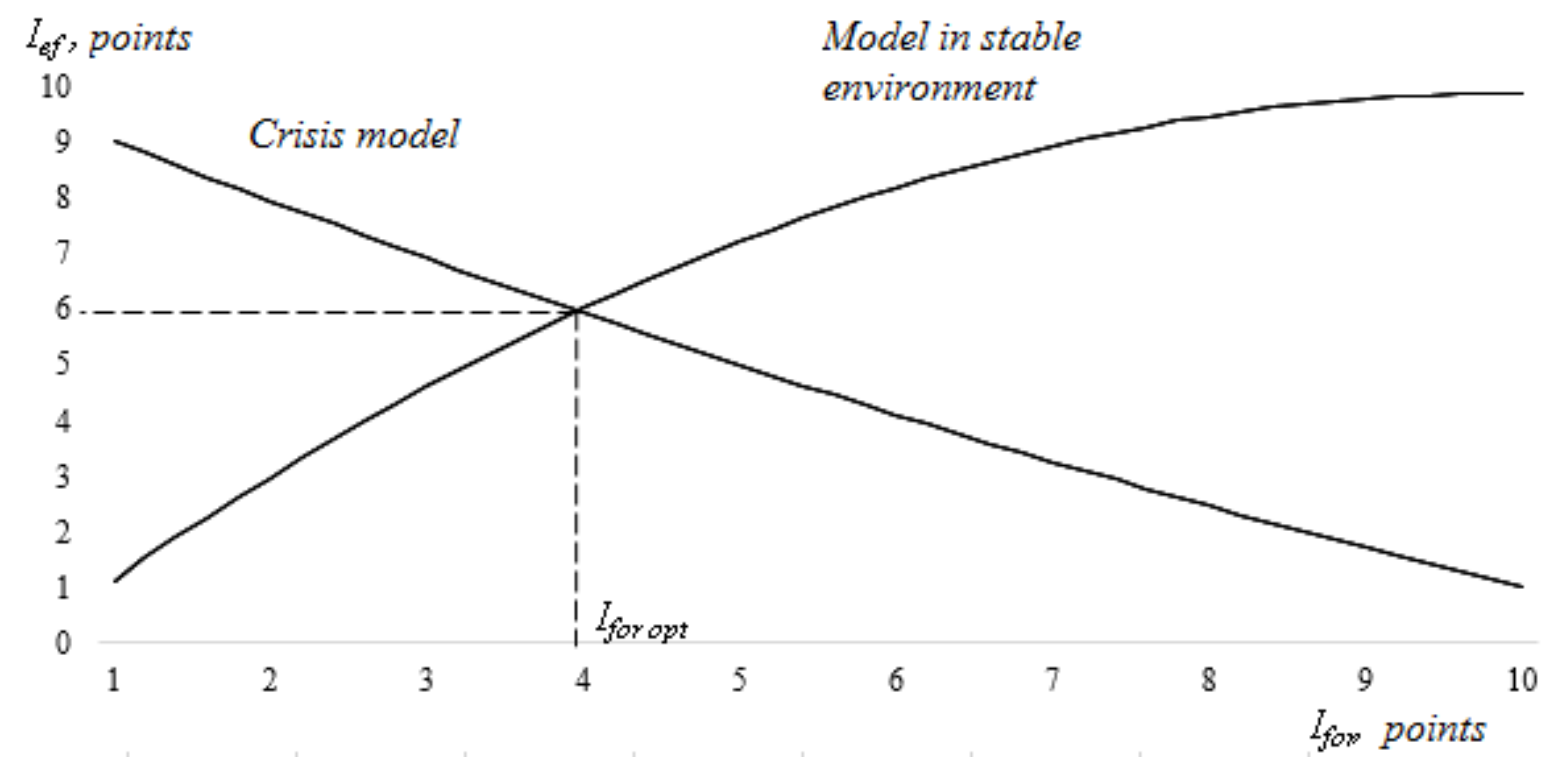

Figure 1. The optimal balance between foreign and domestic suppliers and investors in ensuring the functioning of the VTGI

The optimal value of the indicator of dependence on foreign suppliers and investors is 3.96 points. The estimation range of the $I_{\text {for }}$ is a $[1 ; 10]$ indicator, where a score of 10 corresponds to $100 \%$ dependence on foreign suppliers and investors, and a score of 1 is $0 \%$ dependence. With such a rating system, an estimate of 3.96 points corresponds to the optimal participation of foreign suppliers and investors in ensuring the functioning of enterprises at the level of $44.01 \%$. This supply structure provides efficiency at the level of 5.97 points, which underestimates efficiency in a stable environment but creates conditions for reliable operation in a crisis environment.

\section{DISCUSSION}

In the framework of this study, we have thus empirically simulated the subordination of indicators of the efficiency of economic activity of an enterprise in the VTGI on the level of dependence of cooperation with foreign suppliers and investors. In contrast to the work of researchers (Xiao et al., 2019; Chae et al., 2017; Tescari \& Brito, 2016; Cai et al., 2016), who investigate the impact of dependence on foreign suppliers and investors on the performance of enterprises in conditions of stability, this model is universal. Moreover, it takes into account the peculiarities of the conditions of the functioning and economic activity of a particular industry under study. The proposed econometric approach to determining the optimal balance of interaction between foreign and domestic enterprises in the VTGI is of practical importance as it improves the efficiency of enterprise management both in a stable external market environment and in crisis manifestations in the economy. This approach can be used to define directions for moving up the value chain and creating a national brand image that is competitive and quality oriented. For example, in order to benefit from preferential tariffs under the recently signed European Union-Vietnam Free Trade Agreement (EVFTA) (Deshmukh, 2020), Vietnamese clothing manufacturers must comply with a fabric shipment rule. Also, determining the optimal ratio of domestic and foreign enterprises in the industry will allow for rationally diversifying the volumes and directions of demand for the industry's products. Vietnam should use FTAs, especially the recently signed Comprehensive and Progressive Trans-Pacific Partnership (CPTPP) 
(Massmann, 2020), to tap into new export markets. Manufacturers should also pay more attention to Vietnam's promising domestic market and explore new product offerings.

In its turn, the government should provide direct and indirect financial support for DEs through tax policies, ensuring the equality of incentives for both DEs and FIEs because unequal treatment between FIEs and DEs in government-related policies on tax incentives exists. The government of Vietnam should encourage textile and garment enterprises to invest in scientific research and apply advanced technologies to production. In addition, purchasing advanced technologies transferred from the world-leading companies should be regarded as an appropriate policy in order to narrow the technology gap between FIEs and DEs and meet the requirements of overseas importers.

\section{CONCLUSION}

This research and analysis has resulted in come objective conclusions. Increasing the labor and production efficiency of the VTGI should be done along with restructuring and expanding production, retraining labor, and optimizing the business model to focus on expanding cooperation with national suppliers and the development of demand for products from the domestic consumer. It has been determined that in the context of an escalation of crisis manifestations in the economic conjuncture of the industry under study, the dominance of foreign suppliers and investments in the industry has a destructive effect on its functioning, provoking the threat of bankruptcy on enterprises in the industry. The optimal ratio of interaction between foreign and domestic suppliers and investors was determined empirically. It was determined that the optimal participation of foreign suppliers and investors should be $44.01 \%$ of the total structure of enterprises and industrial capital. This structure of supplies and financing will contribute to a decrease in efficiency in a stable market environment (therefore, in this case, the level of foreign capital of the industry and suppliers can be increased), but it will maximize the economic efficiency of industrial enterprises in an uncertain external environment and level the risk of bankruptcy.

\section{REFERENCES}

Angie, N. T. (2012). Vietnamese textile and garment industry in the global supply chain: state strategies and workers' responses. International Journal of Institutions and Economies, 4, 123-150. Retrieved from https://ijie.um.edu.my/article/view/4866

Anh, D., \& Hanh, H. (2020). Forecast of textile market situation in the last 6 months of 2020. Retrieved from https://vinatex.com.vn/du-bao-tinh-hinhthi-truong-det-may-6-thang-cuoi-nam2020/

Aydın, N., \& Kulali, G. (2018). Asset utilization efficiency and ownership structure: Evidence from emerging and developing Eastern Europe. Journal of Eastern European and Central Asian Research, 5(1), 18. doi: 10.15549/jeecar.v5i1.186

Cai, D., Feng, T., \& Zhang, Z. (2016). The fit between external involvement and business environment: evidence from Chinese manufacturing firms. International Journal of Information Systems and Supply Chain Management, 9(3), 46-64. doi: 10.4018/IJISSCM.2016070103

Chae, S., Choi, T. Y., \& Hur, D. (2017). Buyer power and supplier relationship commitment: a cognitive evaluation theory perspective. Journal of Supply Chain Management, 53(2), 39-60. doi: $10.1111 /$ jscm. 12138

Deshmukh, A. (2020). EU - Vietnam Free Trade Agreement: Vietnam's Competitive Gains. Retrieved from https://globalriskinsights.com/2020/05/euvietnam-free-trade-agreement-vietnamscompetitivegains/\#: :text=On\%20February\%2012th\%2C $\% 202020$,will\%20consequently\%20enter\%20i nto\%20force

Dilip, K. Jh. (2020). Textile demand may decline 25-35\% in FY21 due to slowdown: Report. Retrieved from https://www.businessstandard.com/article/economypolicy/textile-demand-may-decline-25-35- 
in-fy21-due-to-slowdown-report120061900404_1.html

Dubina, I. N. (2006). Mathematical foundations of empirical socio-economic research. Barnaul: Altai University Publishing House.

General Statistics Office of Vietnam. (2020). Retrieved from https://www.gso.gov.vn/en/homepage/

Ha, C. (2019). Cotton Day 2019: Outlook on US cotton import. Retrieved from https://vinatex.com.vn/cotton-day-2019trien-vong-trong-viec-nhap-khau-bonghoa-ky/

Hikmah, K., Haryono, T., \& Djuminah. (2020). Endogeneity test: investment opportunity set and ownership structure on funding policies. Journal of Southwest Jiaotong University, 55(4). Retrieved from http://jsju.org/index.php/journal/article/vie $\mathrm{w} / 652$

Huong, T. V., \& Lam, C. P. (2016). A dynamic approach toassess international competitiveness of Vietnam's garment and textile industry. SpringerPlus, 5, 203. doi: 10.1186/s40064-016-1912-3

Massmann, O. (2020). Vietnam - evaluation of the implementation of the EU-Vietnam Free Trade Agreement and the Comprehensive and Progressive Agreement for Trans-Pacific Partnership. Retrieved from https://blogs.duanemorris.com/vietnam/202 0/07/22/vietnam-evaluation-of-theimplementation-of-the-eu-vietnam-freetrade-agreement-and-the-comprehensiveand-progressive-agreement-for-transpacific-partnership/

Military Bank Securities. (2018). Vietnam Fintech Report. Retrieved from https://www.mbs.com.vn/uploads/files/Baocao-IB/1_-Vietnam-fintechreport_22102018.pdf

Ministry of Planning and Investment. (2020). Brief on foreign direct investment of 2019. Retrieved from http://www.mpi.gov.vn/en/Pages/tinbai.asp $\mathrm{x}$ ? idTin $=45020$ \&idcm $=122$

Nguyen, T. (2020). Seizing investment opportunities in Vietnam's garment and textile industry. Retrieved from https://www.vietnam-

briefing.com/news/seizing-investmentopportunities-vietnams-textile-garmentindustry.html/

Pérez, L., \& Cambra-Fierro, J. J. (2015). Uneven partners: managing the power balance. Journal of Business Strategy, 36(6), 13-21. doi: 10.1108/JBS-10-2014-0126

Phu Hung Securities. (2019). Growth opportunity of Vietnam textiles still continues in 2019. Retrieved from https://www.phs.vn/data/research/PDF_File s/analysis_report/en/20190401/Textiles20190330-E.pdf

Reid, N. (2015). Statistical sufficiency. In J. Wright (Ed.), International encyclopedia of the social \& behavioral sciences (pp. 418422). Elsevier. doi: 10.1016/B978-0-08097086-8.42178-1

Ruan, Q., Zhang, M., Lv, D., \& Yang, H. (2018). SAD and stock returns revisited: Nonlinear analysis based on MF-DCCA and Granger test. Physica A: Statistical Mechanics and its Applications, 509, 1009-1022. doi: 10.1016/j.physa.2018.06.075

Saleh, H., Abubakar, H., \& Suriani, S. (2020). Determining factors affecting the interest in investment in Bulukumba area of South Sulawesi. Journal of Southwest Jiaotong University, 55(1). doi: 10.35741/issn.02582724.55.1.35

Statista. (2020). Apparel industry in Vietnam Statistics \& facts. Retrieved from https://www.statista.com/topics/5820/appa rel-industry-in-vietnam/

Tescari, F. C., \& Brito, L. A. L. (2016). Value creation and capture in buyer-supplier relationships: a new perspective. Revista de Administração de Empresas, 56(5), 474-488. doi: 10.1590/s0034-759020160503

Texprocil. (2020). News clippings. Retrieved from https://texprocil.org/ibtexnewsclipping/IBT EX05082020.pdf

Thuan, L. H. (2017). Report on textile and garment industry. FPT Securities.

Vietnam Customs. (2020). Statistics data. Retrieved from https://customs.gov.vn/Lists/EnglishStatistic 
s/ScheduledData.aspx?Group=Trade\%20anal ysis\&language $=$ en $-U S$

Vlados, Ch. M. (2019). Porter's diamond approaches and the competitiveness web. International Journal of Business Administration, 105), 33-52. doi: 10.5430/ijba.v10n5p33

Xiao, Ch., Petkova, B., Molleman, E., \& van der Vaart, T. (2019). Technology uncertainty in supply chains and supplier involvement: the role of resource dependence. Supply Chain Management, 24(6), 697-709. doi:

10.1108/SCM-10-2017-0334

\section{ABOUT THE AUTHORS}

Dao Thanh Binh, email: ngoctranthibich11@gmail.com

Dao Thanh Binh holds a $\mathrm{PhD}$ in Economics, Lecturer of School of Economics and Management, Hanoi University of Science and Technology, Vietnam. Research interest: finance management.

Tran Si Lam holds a PhD in Economics, Associate Professor, Senior Lecturer of School of Economic and International Business, Foreign Trade University, Hanoi, Vietnam. Research interest: foreign economic relations.

Nguyen Danh Nguyen holds a PhD in Economics, Director of School of Economics and Management, Hanoi University of Science and Technology, Vietnam. Research interest: production and personal management.

Tran Thi Bich Ngoc is a PhD in Economics, Associate Professor, Senior Lecturer of School of Economics and Management, Hanoi University of Science and Technology. Research interest: production management and social affairs.

Galina Anzelmovna Barysheva is a Professor, Director of International Scientific Educational Laboratory for the Improvement of Wellbeing Technologies of Older Adults, Tomsk Polytechnic University, Tomsk, Russia. Research interest: social affairs and well-being. 